\title{
Improving Continuous Assessment Results of Low Achievers Through Peer Learning: The Case of Debre Markos University Burie Campus General Forestry First Year Students Taking Wild Life Management Course
}

\author{
Ayalew Fekadie Addisu Abera Yibeltal Anbes \\ Debre Markos University Burie campus, Collage of Agriculture and Natural Resource \\ PO Box 18, Burie, Ethiopia
}

\begin{abstract}
This action research was conducted in Debre Markos university Burie campus on first year students from General Forestry department with the objective of improving continuous assessment results of low achievers through peer learning. Both primary and secondary data sources were used. The primary data was collected from teachers and students (through questionnaires), direct observations of the real situations related to the practices of peer learning in the classroom and FGD with GF Students. Secondary data was collected from related research works, documents at different lines and from registrar office (students' achievement in the previous semester). Out of a total of 26 students participated in the research, 11 students (4 male \&7 Female) were lower achievers (Below CGPA 2.25). Independent sample t- test at $\mathrm{P}<0.05$ was utilized to check whether there is significant achievement difference between pre-test and post-test of low achiever students achievement. The data obtained through observation and FGD was analyzed using narrative description (qualitative methods of analysis). The number of students who scored below 4.5 in test results was reduced from $1(9.1 \%)$ to $0(0 \%)$ through peer learning intervention.
\end{abstract}

Keywords: Peer learning, lower achievers, Test results, Assignment results

DOI: $10.7176 / \mathrm{JEP} / 10-28-05$

Publication date:October $31^{\text {st }} 2019$

\section{INTRODUCTION}

Education is a means by which people develop and acquire knowledge, skills, values and attitudes. It paves the way for development and plays vital role (serve as a catalyst) in bringing socio-cultural, economical, technological, political and environmental advancements. However, to achieve these goals or to attain quality education, the teaching learning process at all educational institutions should be supported by strong two way communications (teacher students or student's students) meaning active participation had better observed during the whole course provision sessions(Major and Palmer, 2001).

Active learning has attracted strong advocates among educational institutions looking for alternatives to traditional teaching methods (Kumar, 2007).. It involves the use of the mind, not just the memory. It is the process of discovery in which the student is the main agent, not the teacher. i.e. students learn best when learning is active: When they are mentally involved, when they engage in hands-on activities, when they are involved in a process of inquiry, discovery, investigation, and interpretation. Thus, learning is enhanced when students repeat the information in their own words or when they give examples or make use of the information (Bransford et al., 2000).

Peer learning is the attainment of knowledge and skills through active helping and supporting among status equals or matched companions. It is a teaching interaction between students from similar social groupings who are not professional teachers helping each other to learn and learning by themselves by doing so (Topping, 2001). Peer Learning is also defined by Johnston \& MSTL( 2009) as a teaching and learning strategy that involves groups of students working together to solve a problem, complete a task, or create a product. Each member of a team is responsible not only for learning what is taught but also for helping team-mates learn, thus creating an atmosphere of achievement. Students work through the assignment until all group members successfully understand and complete it.

According to Vanauker-Ergle (2012), a low achiever is someone who achieves less than those around him. The author further stated that children who are low achievers generally have a below average (100) IQ and struggle in the classroom to keep up with general academic requirements. Low achievers typically do not qualify for special education services because they do not meet the 70 or below IQ requirement for mentally retarded or the IQ/achievement discrepancy for learning disabled classification. Hensen (2014) in his view stated that low achievers is a term referring to students who are slow learners, disadvantaged, underachieve, and backward in their academic pursuit. 


\section{RESEARCH METHODOLOGY}

Source of Data, Sample Population, Sampling Techniques

The required data was collected both from primary and secondary sources. The primary data sources was collected from teachers and students (through questionnaires), direct observations of the real situations related to the practices of peer learning process in the classroom and FGD with GF Students. Secondary data was collected from related research works, documents at different lines and from registrar office (students' achievement in the previous semester). Out of a total of 26 students participated in the research, 11 students (4 male \&7 Female) were lower achievers (Below CGPA 2.25).

\section{Data Collection Instrument}

To gather information about the practice and challenges of students' peer learning, a variety of tools such as observation, FGD and questionnaires was employed. Questionnaires were used to collect data from students about their perception, roles and problems encountered in the effectiveness of peer learning. Direct classroom observation was conducted to see the extent of students peer learning organization, the support of teachers and participation in peer learning in the entire classroom.

FGD was used to elicit data regarding the teachers and students perception towards the implementation of peer learning, challenges and possible strategies to enhance peer learning and in the class.

\section{Procedures of Data Collection}

Both the campus and the department were informed about the issues, and also the researchers had made the idea clear to the students to let them engage freely in the research. From the beginning of data collection to the intervention the information was accountably communicated.

\section{Methods of Data Analysis}

Quantitative data was analyzed through percentage, mean and frequency. Percentage was utilized to analyze and determine different characteristics and personal background of the respondents. The frequency was utilized to

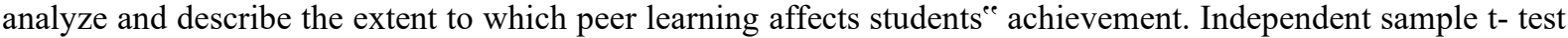
at $\mathrm{P}<0.05$ was utilized to check whether there is significant achievement difference between pre-test and post-test of low achiever students achievement. The data obtained through observation and FGD was analyzed using narrative description (qualitative methods of analysis).

\section{RESULTS AND DISCUSSION}

\section{Students perception on peer learning}

As the result indicated in Table 1, the majority of the students (23\% very high and 38\% high) had interest in peer learning and others have no interest (12\%very low and $27 \%$ low). From this, one can understand that there is a variation of interest in peer learning in the classroom. This also showed the prevalence of knowledge gap on students about peer learning, even though majority (38\%) of them responded that students have knowledge on it.

With regard to student's participation in peer learning as indicated in the table 1,19 and $8 \%$ of the respondents had low and very low participation respectively and 54\% indicated high participation. This indicated that significant numbers of students are reluctant to participate in peer learning. In the case of role of peer learning in improving academic achievement the significant number $46 \%$ of the respondents scaled very high and $34 \%$ respondents scaled high, $12 \%$ respondents scaled low and $8 \%$ of respondents scaled very low. This indicated that there is no uniformity among students about the role and importance of peer learning in improvement of academic achievement.

Table 1: Student's perception on peer learning

\begin{tabular}{|c|c|c|c|c|c|c|c|c|c|}
\hline \multirow[t]{3}{*}{ №. } & \multirow[t]{3}{*}{ Perception measures of peer learning } & \multicolumn{8}{|c|}{ Interest } \\
\hline & & \multicolumn{2}{|c|}{$\begin{array}{l}\text { Very } \\
\text { high }\end{array}$} & \multicolumn{2}{|c|}{ High } & \multicolumn{2}{|c|}{ Low } & \multicolumn{2}{|c|}{$\begin{array}{l}\text { Very } \\
\text { low }\end{array}$} \\
\hline & & $\mathrm{N}$ & $\%$ & $\mathrm{~N}$ & $\%$ & $\mathrm{~N}$ & $\%$ & $\mathrm{~N}$ & $\%$ \\
\hline 1. & Students interest in peer learning & 6 & 23 & 10 & 38 & 7 & 27 & 3 & 12 \\
\hline 2. & Students participation in peer learning & 5 & 19 & 14 & 54 & 5 & 19 & 2 & 8 \\
\hline 3. & Students sharing of different responsibility in peer learning & 3 & 12 & 7 & 27 & 11 & 42 & 5 & 19 \\
\hline 4. & Students knowledge about importance of peer learning & 6 & 23 & 10 & 38 & 7 & 27 & 3 & 12 \\
\hline 5. & Role of peer learning in improving achievement & 9 & 34 & 12 & 46 & 3 & 12 & 2 & 8 \\
\hline 6. & Students awareness of peer learning & 6 & 23 & 10 & 38 & 7 & 27 & 3 & 12 \\
\hline 7. & Students motivation to participate in peer learning & 5 & 19 & 14 & 54 & 5 & 19 & 2 & 8 \\
\hline 8. & $\begin{array}{l}\text { Peer learning creates positive interdependence } \\
\text { Among students in the class room }\end{array}$ & 9 & 34 & 8 & 31 & 3 & 12 & 6 & 23 \\
\hline
\end{tabular}

Note: very high and high: to show their agreements with the ideas of the measurements; and Low and very low: to disagree with the ideas of the measurements of peer learning. 


\section{Results of low achiever students through peer learning intervention}

As Table 2 indicates, the number of students who scored below 4.5(out of ten) reduced in test results from $1(9.1 \%)$ to $0(0 \%)$ and in assignments results from $7(63.6 \%)$ to $0(0 \%)$. The number of students who scored between 5 and 7.5 was also reduced in test results from $9(81.8 \%)$ to $2(18.2 \%)$ but it increases from $4(36.4 \%)$ to $5(45.5 \%)$ in assignments results. In addition to this, the number of students who scored above 7.5 was increased in test results from $1(9.1 \%)$ to $9(81.8 \%)$ and from $0(0 \%)$ to $6(54.5 \%)$ in assignments results. This change indicates that the implementation of the identified actions (peer learning) has great role in improving the achievement of low achiever students.

The number of students who scored between $0-4.5$ before intervention was $1(9.1 \%)$ but no students has scored below 4.5 in post intervention. And also the number of students who scored above 7.5 in test results has increased from $1(9.1 \%)$ before intervention to $9(81.9 \%)$ after intervention. This indicates that peer learning has a great contribution in improving the academic test results of low achieving students.

Table 2: Results of students on pre-intervention test and post intervention -test

\begin{tabular}{|c|c|c|c|c|c|c|c|c|}
\hline \multirow{2}{*}{$\begin{array}{l}\text { Test result } \\
\text { intervals (out of } \\
10 \text { ) }\end{array}$} & \multicolumn{2}{|c|}{$\begin{array}{l}\text { Pre intervention } \\
\text { test Result }\end{array}$} & \multicolumn{2}{|c|}{$\begin{array}{l}\text { Post intervention } \\
\text { test Result }\end{array}$} & \multicolumn{2}{|c|}{$\begin{array}{l}\text { Pre intervention } \\
\text { Assignment Result }\end{array}$} & \multicolumn{2}{|c|}{$\begin{array}{l}\text { Post intervention } \\
\text { assignment Result }\end{array}$} \\
\hline & Frequency & $\%$ & Frequency & $\%$ & $\mathrm{~N}$ & $\%$ & $\mathrm{~N}$ & $\%$ \\
\hline $0-4.5$ & 1 & 9.1 & 0 & 0 & 7 & 63.6 & 0 & 0 \\
\hline $5-7$ & 9 & 81.8 & 2 & 18.2 & 4 & 36.4 & 5 & 45.5 \\
\hline $7.5-10$ & 1 & 9.1 & 9 & 81.8 & 0 & 0 & 6 & 54.5 \\
\hline
\end{tabular}

As indicated in Table 3, the mean test score of students in pre and post intervention test was 5.7727 and 8.3636 respectively. On the other hand the mean assignment score of students in pre and post intervention was 4.4091 and 7.4545 respectively. This indicates that, planned and well-organized implementation of peer learning improves the achievement of students. The result of t- test $(\mathrm{P}<0.05)$, indicates that, there is significant difference in the test and assignment results of students at pre-test and post-test.

Table 3. Paired Samples Statistics

\begin{tabular}{llllll}
\hline Assessment & $\mathrm{N}$ & Mean & Std. Deviation & $\begin{array}{l}\text { Mean } \\
\text { difference }\end{array}$ & P value at $\alpha=0.05$ level \\
\hline Pre test & 11 & 5.7727 & 1.32973 & 2.59091 & 0.001 \\
Post test & 11 & 8.3636 & .92442 & & \\
Pre assignment & 11 & 4.4091 & 1.24133 & 3.04545 & 0.000 \\
Post assignment & 11 & & .98627 & & \\
\hline
\end{tabular}

\section{CONCLUSION AND RECOMMENDATIONS}

\section{Conclusion}

Even though majority of students have good understanding and better awareness on peer learning, there is no uniformity of understanding among students about peer learning. Some students are reluctant or do not fully participate in peer learning. There is a gap in practicing peer learning among studensts in the classroom. A significant number of students did not clearly know what peer learning is and the implication is that there is the need for awareness rising program for the students in the classroom to help all learners have common understanding of peer learning.

\section{Recommendations}

According to the finding the following set of recommendations are forwarded

$\checkmark \quad$ It is better to create awareness for students about peer learning to bring attitudinal change and enhance students active involvement

$\checkmark$ A close supervision of students is needed to insure the effectiveness of peer learning

$\checkmark \quad$ It is necessary to structure and organize the peer group for peer learning and by pairing low achievers with high achiever

\section{REFERENCES}

Bransford, J., Brown, A.and Cocking, R. (2000). "How People Learn: Body, Mind, Experience and School," NationalAcademy Press, Washington D.C.,. Available online at http://www.nap.edu/html/howpeople.

Hensen, C. (2014). Four track curriculum for today's high schools. Englewood Cliffs, Prentice-Hall.

Kumar, R. (2007). Students' classroom participation for improved learning in an English language skills course: An Action Research Report, University of the South Pacific

Major, C., and B. Palmer, (2001). "Assessing the Effectiveness of Problem-Based Learning in Higher Education: Lessons from the Literature,’'Academic Exchange Quarterly, Vol. 5, No. 1,

Ms Jennifer Johnston and NCE-MSTL (2009). How to Implement Peer Learning in Your Classroom. Resource \& Research Guides Vol. 1 \#7. 
Topping, K.J. \& Ehly, S. (2001). Peer assisted learning: a framework for consultation. Journal of Educational and Psychological Consultation. 12(2):113-132.

Vanauker-Ergle, K.A. (2012). Barriers to low achievers' success in the elementary classroom as perceived by teachers: A qualitative study. Unpublished Ph.D. Dissertation. Graduate school of the University of Florida. 